\title{
The Development of Jaranan Temanggungan as Indonesian Intangible Heritage
}

\author{
Slamet \\ Indonesia Institute of the Arts, Surakarta, Indonesia
}

\begin{abstract}
Margowati was a village in Temanggung Regency. This village had the potential to be used as a tourist village. In Kapalan Hamlet there was a site similar with horse breeding grounds, marked with inscriptions in the form of horse footprint. This finding was also related to the name of the hamlet called Kapalan, which was another name for horse. Most of the Kapalan Hamlet people made handicrafts related to horses, such as kuda kepang (horseshaped toys made of woven bamboo slats). The famous form of art was a Jaranan dance, or usually was called as Kuda Lumping. This research was about the identity of Jaranan dance in Temanggung Regency. Although Jaranan dance was found in many regions in Indonesia, each region had different characteristic. This research was a study of Jaranan Temanggungan as intangible cultural heritage. Jaranan was designated as an icon of intangible cultural heritage, not only from historical factors, but because of its current position in society. The form of choreography and performance of Jaranan was closely related to the function of Jaranan in its supporting community. Temanggung style Jaranan dance patterns had a distinctive characteristic hence it was called Jaranan Temanggungan. This research needed to be done to find out the dance pattern of Jaranan Temanggungan and the connection of Jaranan Temanggungan to the site of Kapalan Hamlet, Margowati Village. Specific objective to be achieved was to provide knowledge and understanding for the wider community about the dance patterns of Jaranan Temanggungan choreography for further development. The output of this research was to produce a written study of intangible cultural heritage as well as to produce new dance patterns that form the Jaranan Temanggungan choreography.
\end{abstract}

Keywords: Jaranan Temanggungan, intangible cultural heritage, dance pattern, choreography

DOI: $10.7176 / \mathrm{ADS} / 77-06$

Publication date:October $31^{\text {st }} 2019$

\section{Introduction}

In ancient times our ancestors had the belief to worship ancestral spirits (animism), and worship some supernatural powers (dynamism). This belief was related to the cultural and religious system of the community when it was believed that around them there were still spirits that lived in the world. Spiritual dwelling places around them were in the rocks, big trees, and all areas that looked haunted. At times when these ancestral spirits were asked to come back to the mortal world, their presence was always marked in many ways. One method was believed to be with certain spells or with certain offerings. In addition, they often also used a person's physical body as an intermediary for the arrival of ancestral spirits. Therefore, art was a means of certain people who believed in this tradition and belief. Gamelan and Jaran Kepang were some of them.

The fact showed that people in the mythic world of thought still had a mentality of simplicity. This always carried with them the lack of confidence they had. The situation would make it easier for them to be influenced by the sound of music or thunderous, monotonous and constant patterns. A constant pattern without complicated standards of beauty had traditionally been very easy to provoke dancers' unconscious minds. Usually, this action caused mental imbalance, which would result in trance or possession. This unbalanced soul would be entered by the spirit. During possession, the dancer's body would be borrowed by a spirit from another world. In general, the situation when a dancer experienced trance,was becoming an interesting attraction. This tradition was finally considered normal, and a trance situation could occur without the need to be provoked. In short, the concept of trance could no longer be measured in aesthetic standards according to the beauty of art. Finally, this tradition was considered normal.

Tradition-based performance was actually considered as a custom that did not have bad impact on society. But the development of society towards modernity changed the pattern of old customs, so that the continuation of art also changed. The development of thinking in the communityhad changed the belief system into a new knowledge system when addressing the need to package performances. One thing that was maintained in the general pattern of old habits was the association of this dance with traditional ceremonies such as Bersih Dusun, Sadranan, or welcoming important guests. This alteration in way of thinking also affected the view that, every time a trance actually occured, the community was aware of the risk of damage to the human soul. The majority of people who had embraced Islam consider that possession was not permissible. Moreover, Pancasila and the grandeur of Indonesian culture required aesthetic aspects as a form of presentation of the excellence of art, adapted to the existing rules. One of the efforts to address the aesthetic presentation of traditional arts was related to human character and mental development in accordance with noble culture. 
How to perform Jaranan Temanggungan in Temanggung area was very diverse, some still maintained the trance tradition, but many had featured the aesthetic aspects of this dance. Jaranan choreography in Temanggung area still showed the typical pattern of Jaranan Temanggungan. The motion patterns were used by almost all groups or at least groups of Jaranan Temanggungan.

The discussion about Jaranan Temenggungan related to dance, because Jaranan Temanggung contained dance elements in it. It has been mentioned above that Jaranan Temanggungan was composed of almost identical motion patterns, used throughout the Temanggung area. This was due to the fact that dance wasa branch of art that used the dimensions of motion, time, and energy as its constituent elements. Dance was a human feeling expressed through human body movements. The motions in dance were not the motions that we experienced everyday, nor the real motions (wantab) of someone who was doing activities at any time, but weremotions that had undergone the processes and changes of daily movements. Dance could be said as a science, which was formed by the dance forming elements which were said to be dance forming science consisting of motion, expression, rhythm, cosmetology, costumes, stage performances, and dancers (Slamet: 201640 ).

Jaranan was a folk dance that reflected the expression of people living outside the palace (commoners). Folk dance had two functions, namely functions related to traditional or religious ceremonies and functions related to entertainment. Dance that functioned for ceremonies was usually sacred and had magical powers, and those related to entertainment are usually used as social or pleasure dances. Hence, It could be understood that Jaranan Temanggungan was an expression of Temanggung community. The dance was affected by people's activities and geographical environment.

Kuda Lumping was a folk art that lived and developed from generation to generation. Jaranan was born and developed in the midst of rural communities. Community life was still related to traditions and customs which were still very strong. Therefore, Kuda Lumping could be used for community needs in their life.

Jaranan Temanggungan was usually performed in groups consisting of dancers who acted as male and female warriors. Dancers usually used horses made of plaited bamboo or made of animal skin which was made to resemble an imitation of a horse. In Kentengsari Village, Candiroto Subdistrict, Temanggung Regency, Jaranan was performed every time the village organized events such as sadranan, commemoration of the Prophet Muhammad's Birthday, commemoration of the month of Sura, weddings, circumcision events, and so on. Jaranan in Kentengsari Village had good prospects to continue to grow and develop into one of the cultural assets owned by Indonesia (Delvi Saraswati, 2016: 4).

Jaranan Temanggungan was a dance that was played using a horse-like tool made of thin bamboo slats that were plaited and colored. Regarding the origin of Jaranan in Temanggung, several versions of the story were circulating. That said, Jaranan told the history of Raden Patah's struggle - who was assisted by Sunan Kalijaga, fighting against the Dutch invaders. Some explained that Jaranan Temanggungan was a form of popular support for Prince Diponegoro's cavalry against the Dutch invaders. In another version it stated that, Jaranan described the soldiers of the Mataram Kingdom who were practicing combat and were led by Joko Kathilan and assisted by two servants named Pentul and Bejer.

Based on those stories, it could be concluded that Jaranan played a role as: (1) sacred rituals in the village cleansing ceremony; (2) performing arts; (3) entertainment. Looking at the word 'ritual', we would imagine a magical atmosphere in the performance. Jaranan was an art form that had always been used as a means to directly involve the community in performances. On the other hand, Jaranan could quickly develop among the people and could not escape from the life order of the people in its environment. The community was directly involved in the performance, so Jaranan became the closest form of art to express the life system of the people around it.

Regardless of its origin and historical value, Jaranan was a form of heroism and military spirit possessed by cavalry forces. This could be seen from the dynamic, rhythmic, and aggressive movements that were shown through the flapping of horses like when in the middle of a battle. In Kuda Lumping show there were dancers who displayed magical supernatural powers. The attraction reflected supernatural power that many people used to have in Javanese Kingdom environment, and was a non-military aspect to fight the Dutch invaders. In this case Kuda Lumping hereinafter referred to as Jaran Kepang or better known as Jaranan.

The existence of Jaranan in Temanggung was considered as a result of traditional innovation, it was said that because Jaranan Temanggungan had now developed into a dance performance with aesthetic choreography. But in the performances, Jaranan Temanggungan still showed Temanggung's characteristics as its traditional inheritance.

The opinion mention above triggered research that could reveal the following problems.

a. How was the patterns of Jaranan Temanggungan formed?

b. How was the form of innovation in Jaranan Temanggungan development as folks tradition?

The purpose of this study was to provide knowledge and understanding to the wider society regarding Jaranan Temanggungan's innovation and development as traditional folk art.

The specific purpose of this research to be achieved was to provide knowledge and understanding to the 
public in general regarding the form of folks choreography development and innovation in Jaranan Temanggungan.

Discussions on Jaranan were often found, either written by researchers both domestically and abroad. While discussions on jaranan in the form of writings on Jaranan Temanggungan especially those relating to innovation and the development of folks-based choreography, were still very limited or even non-existent. However the literature on Jaranan Temanggungan did not exist at all, often the discussion becomes a part of the discussion about Jaranan dance in general.

In the Kamus Besar Bahasa Indonesia (Indonesia Complete Dictionary), Kuda Lumping was a leather toy horse or from plaited bamboo slats that were used as equipment in Kuda Lumping dance. The dance moves resembled a horse. Kuda Lumping had several other terms in some areas such as Jaran Kepang and Jathilan. Kuda Lumping was a famous dance on the Island of Java. Kuda Kepang Jawawas an example of the preservation of a living tradition, but only in its form (Holt, 2000: 130). Koentjaraningrat, said that Jaranan is one of the folk arts or traditional arts. Besides Jaranan, there is also a similar kind of art but with another name, namely Jaran Kepang, Kuda Lumping, Jathilan, or horse dance. This art form is a dance performance (Koentjaraningrat: 2009, 298-299).

The research of Fransiskus Indra Udhi Prabowo stated that twelve dancers were riding horse toys/Jaran Kepang. He stated that this dance was accompanied by music, especially gamelan instruments, it was said that, Jaranan was mostly found in Tulungagung, Blitar, Nganjuk, Kediri, and surrounding areas. Each region even each dance group had its own variety or characteristics in terms of equipments, musical instruments, choreography, and so on. So Jaranan had a variety of appearances. In Yogyakarta, especially outside the Palace, arts like Jaranan were known as Jathilan. Its main property was toys made from sesek (plaited bamboo slats), the shape was neither too big nor too small. The range of motion was more dynamic, tends to be done in a group and was dominated by leg movements. In Ponorogo, Kuda Kepang or Jaranan dance or Jathilan dance was played with dhadhak merak, bujangganong (ganongan), warok, and Prabu Klana. The dance movements were more subtle and feminine. The costume was in the form of an iket, which was a black cloth headscarf that had a triangle shape. Jaranan was basically an art in the form of dance that used equipment in the form of jaranan or horse toys made from plaited bamboo slats. In general, the form of the show also had a similar appearance. The difference from each region was the form of motion, range of motion, costumes, music that accompanies, and the shape of the instrument, as well as how to sound the instrument itself. These differences cannot be separated from the ethnic groups that influence it (Indra Udhi Prabowo, Fransiskus: 2015, 104).

Salamun Kaulam conducted research, "Simbolisme dalam Kesenian Jaranan"in the Jurnal Seni Rupa, Vol. 1, No. 2, December 2012. He stated that in terms of the meaning of the word, 'jaranan' derived from the word 'jaran' or horse and the suffix '-an' indicated a form that was not original or jaran-shaped toy. In Javanese culture, 'jaran' or horsewas an animal that was a symbol of strength, a symbol of might, and a symbol of loyalty. When humans used horses as their vehicles, humans were described as struggling through their life to achieve their life goals. It was said that in the beginning, Jaranan showwas a ritual-related activity involving the ceremonial calling of ancestral spirits performed by our ancestors. This ritual activity aimed to overcome various calamities that befall human life. In primitive times there was a belief that damage to the natural environment, epidemics, disasters, and so on, happened because of the strength of ancestral spirits. Over time, every disaster, distress, or various problems in life related to the spirits of the ancestors were arranged into a series of stories that developed into myths. Myth was believed by the public. They then carried out ritual ceremonies with the aim that the disaster would not come again. Activities that take place repeatedly, then developed into various symbols that are used for ritual activities (Salamun Kaulam: 2012, 132-133).

Literature review above gave an overview of the research to be conducted. As a research road map so there was no duplication of research.

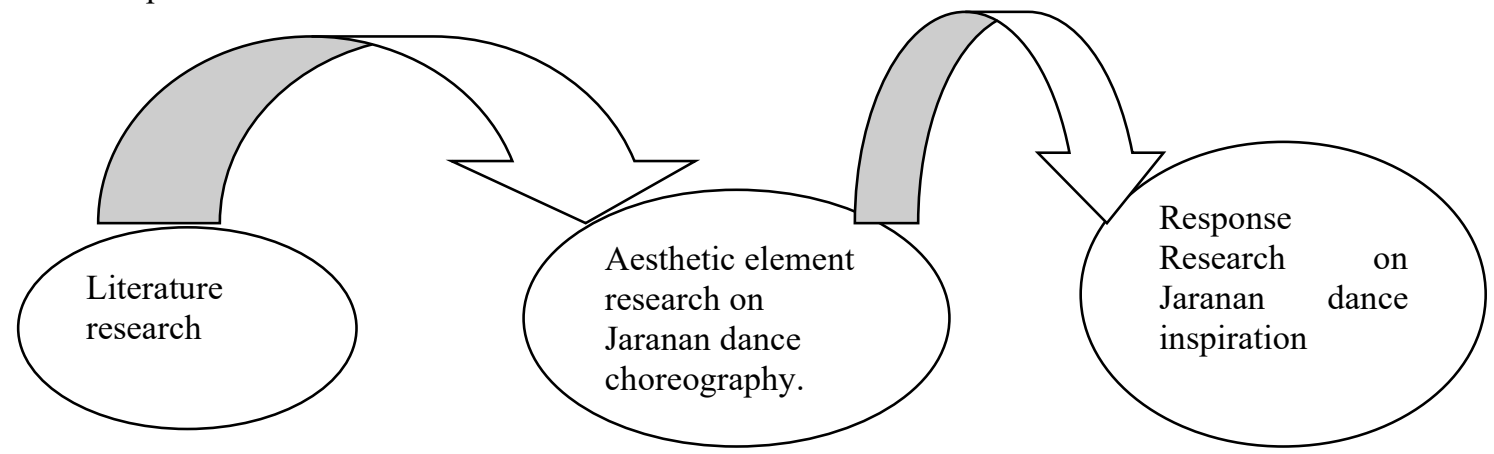

Creating art works in academic environment should be done through several stages that could be scientifically justified. The works of art creation or artistic research was a scientific activity: reseach by practice 
in the sense of research on community phenomena became an idea expressed in a form called a work of art. So there needed to be systematic steps in the process of creating art. The steps of art creating process were as follows.

I made observations by becoming participant and non-participant. I was participating directly in Jaranan show that was by directly involved in Jaranan show in Temanggung. While the observations obtained in this activity were able to perform Jaranan Temanggung motions techniques and experienced the performance of Jaranan directly. This was used to compile and format motion techniques and dance music formats in Jaranan performance model. Non-participant observation observed Jaranan performances in Temanggung by becoming a spectator with the intention of wholly watching the form of the performance.

Interviews were conducted with informants to get information about Jaranan in Temanggung. Then interviews were conducted with Jaranan artists to get information about Jaranan movement techniques, dance music, Jaran Kepang equipments. In addition interviews were conducted with the public and the audience to obtain information about various Jaranan shows.

Literature study was conducted to find references related to Jaranan Temanggungan and the customs of the Temanggung community as an effort to complete references or information about the function and form of Jaranan Temanggungan shows.

This research not only produced a written concept but was also carried out by making a Jaranan Temanggungan model. At this stage there was a flow in the process of creating Jaranan Temanggungan's works of arts.

a. Observation was a method carried out in the initial stages of research. The implementation was by observing community activities in using Jaranan dance both in rituals and performances. This observation produced data on the forms of jaran equipments, techniques for performing Jaranan dances, as well as patterns of motion. The data was then processed into a form called Jaranan Temanggungan.

b. Exploration was a way to look for possibilities based on observational data in the form of a Jaranan Temanggungan show. Observed data and library data were used as a basis for searching for the possibilities of Jaranan Temanggungan model which was then arranged in the form of a scenario. This could later change after the experiment.

c. Experimentation was an advanced method of exploration. This stage was carried out as an experimental stage of the possibilities of searching for a model. Then from the experiments an appropriate technique, work pattern, and model for reflection on the data, would be obtained.

d. Contemplation was a method in the form of a review of exploration and experimentation before ascertaining a form of performance model from Jaranan Temanggungan. Thus contemplation required some consideration of the resulting scenario. Then it was necessary to consider the condition of the community, the performance model, and its users. In other words, how the model was made, used, and published (made used and professional-publication).

e. Formation. This method was the final stage before being socialized or trained. The formation was done after observing and contemplating the results of the experiments. If the results were deemed to have achieved the desired goal, the next step was to determine the forms, starting from the patterns of movement, costume-making, stage, dance, story patterns relating to the script and scenarios that had been considered in accordance with the objectives.

f. Training. Training was an important stage. Before the performance model was staged, the training needs to be done and this training was intended not only as a final performance, but as a socialization of the dance model that was being performed.

\section{Dissussion}

\section{a. The Formation of Jaranan Temanggung'sMotions Pattern}

Javanese people often referred to Jaranan with the term Jaran Kepang. This term was used in almost all regions of Java. Jaran Kepang performances in Temanggung were found in almost every village and in rural areas. Temanggung community called it "aranan" with JK or Jaran Kepang also called it Kuda Lumping. Jaranan or Kuda Lumping was a traditional Javanese dance in the form of a horse riding dance played by a group of people with accompaniment of gamelan music (Kaulam, 2012: 131).

Jaranan dance in Temanggung had its own characteristics from the patterns of motion that were displayed. This dance had the characteristics of legs raised high and dynamic rhythm patterns. This was what made Jaranan Temanggungan need further study. Jaranan Temanggungan could not be separated from the historical factors and the geographical conditions of the region. Referring to the opinion of Lono Simatupang (2013) Jaranan Temanggungan Show was an event that could be said to be a performance. Performance was a spectacle built on unfamiliarity, being at the threshold point, which was witnessing things that were not found in daily life. Time, space, sound, light, motion, utterance, and materials also shaped this unfamiliarity. This show then had several conditions: first, it was an activity that had the will to show something. Second, there was an unusual thing that 
became an attraction. The two previous conditions produced a third condition, which was showing something so that the audience or the public experienced something unusual.

Jarananan Temanggungan Show was a spectacle that contained the forming characteristics of the unfamiliarity. This could be marked from the fact, that Jaranan Temanggungan contained elements that were not common in everyday life. These unusual things like the attraction of possession, made Jaranan Temanggungan no longer considered as a performance but rather seen as a spectacle in the context of society.

Discussion about Jaranan Temanggungan in this case was related to Margowati Village, an old village in the Temanggung Regency area of Central Java. Margowati Village was an old village that had been known since the days of Islamic Mataram established in the XVI century. The book of Serat Centhini mentions the name of Margowati Village in the days of Panembahan Senapati, the first Islamic Mataram king, as a forest for training and sorting the court's chosen horses (Serat Centhini translated by Komajaya, 1981: 47-49). As a place that was considered important, the name of Margowati Village was preserved to date by the community in the Temanggung Regency area. This could be proven by the names of ancestral heritage spaces marked by Dusun Kapal, Gunung Jaran, and a number of names or terms that were closely related to horses (interview with Didik S, Head of Arts Department, Disparbud, Temanggung Regency, February 6, 2015). This study seeked to examine the strategic value inherent in the elements of the village myth which had been preserved for three centuries and continued to be characterized by the performance of dance as a local community activity.

The Temanggung Regency Government in a workshop session "Pengembangan Strategis Pariwisata Budaya" on February 6, 2015 was interested in exploring the value of certain village sites as an effort to develop regional assets. Presumably, starting with a village that had strong historical value and the site was considered to have links with the direction of development and local government policies, Margowati Village was a choice that was very relevant to the strength that would have a wide impact on future research. The phenomenon that appeared in this study was that the art expression presented in the Margowati Village region had a fairly close connection with the beliefs, ideas, understandings of the participants or the potential of the performing arts.

Tracing Jaranan performance that developed in Temanggung, it was understood that the presence of Jaranan was related to the Kapalan Hamlet and Margowati village, as a place for breeding the Mataram Islam's war horse. These results proved the patterns of motion obtained from tracing and observation in Temanggung became clearer. The motions of Jaranan Temanggung were different from Jaranan in other areas, such as theJaranan in Magelang, a region close to Temanggung. Jaranan Magelang put more emphasis on the gallant movement of the horsemen. The dance was more describing the rider. Meanwhile, in Jaranan Temanggung, the dance movement was more focused on the strength of war horses, as an illustration of the war horses in Margowati. The tracesdescribedmotions of horse strength such as; Pengkalan, cekahar, bokongan, tekur-tekur, pengkolan, teposan, gebesan, liyepan, timpangan, sembiran, lampah balik, Nyongklang, and Ngombe.

The creation of Temanggung motion patterns could not be separated from community activities. When searching, the village of Margowati was found with all the potential it had, as explained above, as an area with a heritage site for the Mataram war horse care. The site was in the form of footprints on rocks and a horse drinking area in Kapalan.

Kapalan Hamlet was a name taken from the word 'kapal' which meant 'horse'. Therefore it could be understood that the people in Margowati and Kapalan lived their lives as craftsmen of Jaran Kepang and made other handicrafts that were related in jaranan performance. This understanding made a proof that was related to the understanding that kedogan jaran (horse keeping stable) supported a belief in sympathetic magic. The belief in the power of horse totemism made the Kapalan people created dummy horses, which at that time were used to bring totemism animals so that their horses could be strong and protected from plague. People's habits at that time made a form of Jaranan. The motions that emerged from horse toys became a dance, now known as jaranan dance. The pattern of motion that was formed at this time was an imitation of the motion of a horse and its keepers. Like the motion of ngombe (drinking), the motion of ngudang jaran (praising pet horses), and the motion of nyongklang (gallantry of running horses).

\section{b. The Innovation of Jaranan Jaranggungan's Development as a Folk Tradition}

The motion that was formed came from community's traditions in handling jaran or horses started from the, Kapalan Hamlet community's beliefs, which later developed into a community tradition in a Jaranan performance in Temanggung. These dance motions were then developed into Jaranan Temanggungan treatment model, a treatment that was based on the Temanggung people's tradition. It emphasized more on the patterns of motion that described the strength of the horse. The show began with 'ngudang jaran' motion and continued to 'sembahan', followed by other motion patterns that described the strength of the horse. Jaranan Temanggung's motions pattern was once worked on by IDAKEB, which was an organization under the Indonesia Ministry of Education and Culture at that time. This treatment was done to facilitate the practice of Jaran Kepang or Jaranan show. This note had been used as a standard pattern for the practice performance of Jaranan since 1972 (IDAKEB: 1972, 11-18). 


\begin{tabular}{|c|c|c|}
\hline No & Motion Variety Names & Method of Dancing \\
\hline 1. & Sikap Pokok & $\begin{array}{l}\text { 1. Ngadak mendak sak wetawis, dengkul katekuk, suku arah miring, posisi } \\
\text { tungkak sawetewis sapecak. }\end{array}$ \\
\hline 2. & Cakahar & $\begin{array}{l}\text { 2. Sikap pokok mlampah biasa, suku dipun angkat sewetawis inggil, mlampah } \\
\text { majeng/ mundur arah zik-zak (serong ngiwa nengen). Polatan ngiwa } \\
\text { nengen gagah. }\end{array}$ \\
\hline 3. & Bokongan & $\begin{array}{l}\text { 3. Mlampah sikap pokok prinsip ngegolaken bokong. Tungkak katarik majeng } \\
\text { jangga gela-gelo. }\end{array}$ \\
\hline 4. & Takur-takur & $\begin{array}{l}\text { 4. Siku kiwa megar, maku sanesipun katarik maju dipun tengkuraken kaping } \\
\text { tiga, terus pincangan majeng kaping tiga. }\end{array}$ \\
\hline 5. & Pincangan & $\begin{array}{l}\text { 5. Suku kiwa manggon, suku tengen njinjit njangkah majeng ngegol (nyendal } \\
\text { pencing). }\end{array}$ \\
\hline 6. & Pengkalan & $\begin{array}{l}\text { 6. Siku kiwa manggon, siku tengen dipun pengkalaken/ mancal kaliyan } \\
\text { mlampah majeng. }\end{array}$ \\
\hline 7. & Teposan & $\begin{array}{l}\text { 7. Mlampahipun miring ngiwa/nengen. Yen manegar. Siku tengen dipun } \\
\text { padal, bokong dipun puter, ogek lambung menongan, suku kiwa dipun } \\
\text { pindah gantos menegar, siku tengen age age mlangkah pindah anuranggan } \\
\text { alon alon lan salajengipun kaping tiga, wacana ingkang kaping sekawan } \\
\text { mlonjak nengen mboten pindah. }\end{array}$ \\
\hline 8. & Sakbasan & 8. Sirah kiwa dipun abit abit aken kiwa tengen antal lan sesek. \\
\hline 9. & Menakjinggoan & $\begin{array}{l}\text { 9. Sikap kados yen pinangan, lampahipun njangkah pindah siku kiwa katarik } \\
\text { gedrug kaping kalih (ngoncak bokong) }\end{array}$ \\
\hline 10. & Bapangan & $\begin{array}{l}\text { 10. Siku tangan dipun angkat, tumpak malih kanthi muter badan ngglebag 180' } \\
\text { suku kiwa gantung terus seleh, kiwa gantung seleh. Kalajengaken pacak } \\
\text { jangga kaping kalih. gentosan suku kiwa gantung seleh muter ngglebag } \\
\text { 180'gantung tangen seleh, gantung kiwa/tengen. Djangga. }\end{array}$ \\
\hline 11 & Liyepan/Lemesan & $\begin{array}{l}\text { 11. Suku tengen njangkah majeng lurus badan tumungkul (bungkuk) sirah kuda } \\
\text { dipun horog horog yen suku tangan sampun tumpak, age age narik suku } \\
\text { kiwa cepet kajunjung terus mlangkah kados suku tangan saterusipun } \\
\text { gantosan. }\end{array}$ \\
\hline 12. & Timpangan & $\begin{array}{l}\text { 12. Suku tangen mlangkah badan miring ngiwa. Terus suku kiwa mlangkah, } \\
\text { badan serong menthang. Suku tangan gantung, lajeng mlethik mundur kalih } \\
\text { langkah langsung gantung suku kiwa. Lajeng mlangkah kados suku tengen } \\
\text { gantosan muter, arah manengen. Polatanipun yen mletik mundur ndangak } \\
\text { semu gembelengan. }\end{array}$ \\
\hline 13. & $\begin{array}{l}\text { Untu talang } \\
\text { (untulankasar) }\end{array}$ & $\begin{array}{l}\text { 13. Mlajar nguntul, suku kiwa mlangkah sekawan etangan mandeg. jangga } \\
\text { nglongok mangajeng, mripat mlotot, untu aringis kalijan, bales Hoheh } \\
\text { hoheh (galek). Age age mbalik nguntul malih suku tengen mlangkah } \\
\text { sekawan etangan mandeg. Pancak jangga lan mesem mesem. Sateripun } \\
\text { kanti bolak-balik, yen arah mlebetipun mangiwo. yen arah njawi balikinpun } \\
\text { manengen. }\end{array}$ \\
\hline 14. & $\begin{array}{l}\text { Sembiran } \\
\text { (untulanalus) }\end{array}$ & $\begin{array}{l}\text { 14. Nguntul mlebet sirah tumungkul 4etangan, lajeng gela gelo, nguntul malih, } \\
\text { ndengengok } 4 \text { etangan jangga gela-gelo. }\end{array}$ \\
\hline 15 . & Mager Timun & $\begin{array}{l}\text { 15. Tangan kiwa miwir sampur mlampah sikap pokok suku mekekeh. } \\
\text { jangkahipun dlamakan arah miring ngeged-ngeged. (njendal-njendal). }\end{array}$ \\
\hline 16. & Lenjitan & $\begin{array}{l}\text { 16. Sami kaliyan pincangan namung suku tengen mboten jinjit, tur jangkahipun } \\
\text { alit, suku mboten usah dipun angkat inggil, wirama sajak kesel (lenjit- } \\
\text { lenjit). }\end{array}$ \\
\hline 17. & Legehan & $\begin{array}{l}\text { 17. Sami kaliyan bokongan ngangkatipun suku andap kemawon tumapak biasa. } \\
\text { Tungkak boten usah dipun tarik (wirama sejak kesel), legeh legeh bebas. }\end{array}$ \\
\hline 18. & Lampah Jangga & $\begin{array}{l}\text { 18. Suku kiwa/tengen njangkah, kasusul suku tengen/kiwa njangkah, suku } \\
\text { ingkang wonten wingking katarik mundur ingkang ngajeng nututi mundur } \\
\text { tur jinjit lajeng ngencot bokong, lajeng pacakjangga kaping kalih. }\end{array}$ \\
\hline 19. & Lampah Kletik & $\begin{array}{l}\text { 19. Njangkah majeng tigang langkah dipun wiwiti suku tengen. Terus. Terus } \\
\text { mletik suku kiwa manggen wonten tilasipun dlamakan suku tengen, suku } \\
\text { tengen age age gantung, saklajengipun. }\end{array}$ \\
\hline
\end{tabular}




\begin{tabular}{|c|c|c|}
\hline No & Motion Variety Names & Method of Dancing \\
\hline 20. & Lampah balik & $\begin{array}{l}\text { 20. Kados lampah mletik namung saksampunipun tigang langkah lajeng balik } \\
\text { muter 180' suku kiwa kabucal terus gantung suku tengen saklajengipun } \\
\text { kanti balik arah mangiwa. }\end{array}$ \\
\hline 21. & Lampah Satriyan & $\begin{array}{l}\text { 21. Suku tengen mlangkah majeng suku kiwa katarik terus ngencot. Dipun } \\
\text { ambali ngracik (1/2 langkah kaping kalih)' kendel sawetawis suku ngajeng } \\
\text { madal, (jinjit sadaya) tungkak dipun puter mengajeng (tangan kiwa tengen } \\
\text { kiwa) wirama ngenjak/ngece. }\end{array}$ \\
\hline 22. & Kirig -kirig & $\begin{array}{l}\text { 22. Jomblo manggen terus kirig kirig majeng utawi mundur, yen lajeng polatan } \\
\text { tumungkul, yen mundur polatan ndangak, kudanipun horog horog galak. }\end{array}$ \\
\hline 23 , & Sirig-sirig & 23. Jomblo manggen terus sirig ngiwa/nengen ngentrig entrig \\
\hline 24. & Gejug & $\begin{array}{l}\text { 24. Campuran, njih sirig njih kados mletik, balikjomblo (bebas galak). Wekdal } \\
\text { gajul punika saged kangge perang campuh. Dene yen perang tunggal. } \\
\text { Ingkang gajul namung sepasang, sanesipun wirogo nglaras (lejitan, } \\
\text { legehan). Namung yen pasanganipun perang pinuju gitikan, sedaya tumut } \\
\text { kirig. Perang perangan sagedipun kreasi piyambak, perang pedang, gada, } \\
\text { tumbak. }\end{array}$ \\
\hline 25. & Mekakan & 25. Mlampah mundur gagah badan sawetawis minger minger kuda ndangak. \\
\hline 26. & Drap & $\begin{array}{l}\text { 26. Mlajar suku dipun tekuk dipun angkat inggil, sirah kuda dipun horog horog } \\
\text { galak lan serem. }\end{array}$ \\
\hline 27. & Congklang & $\begin{array}{l}\text { 27. Mlajar suku slonjor kuda ndangak, badan condong mawingking wiraga } \\
\text { kados drap, galak/serem. }\end{array}$ \\
\hline 28. & Malang Kadak & $\begin{array}{l}\text { 28. Mlampah mundur arah mirang miring bolak-balik wetah 180' sak langkah } \\
\text { ngencot bokong sikap pokok. Kuda saged dipun tumpaki saged dipun } \\
\text { cepengi. }\end{array}$ \\
\hline 29. & Srimpetan & $\begin{array}{l}\text { 29. Mlampah miring ngiwa utawi nengen. Yen ngiwa suku tengen njangkah } \\
\text { medal wingkingipun suku kiwa terus suku kiwa nututi njangkah mangiwa } \\
\text { sak terusinpun. Kuda saged dipun tumpakisaged dipun cepengi. }\end{array}$ \\
\hline 30. & Ngombe & $\begin{array}{l}\text { 30. Mapan manggen suku tengen wonten wingking, kiwa ngajeng sirah kuda } \\
\text { tumungkul (ngombe) suku tengen setengah gantung lajeng kuda ndangak } \\
\text { suku kiwa } 1 / 2 \text { gantung lan sak terusipun. }\end{array}$ \\
\hline 31. & Ngantuk & $\begin{array}{l}\text { 31. Suku manggen sejajar yen suku kiwo dipun tekuk jinjit, badan lemes } \\
\text { condong mengiwo, kanti kuda sajak liyer-liyer gantosan sakterusipun. }\end{array}$ \\
\hline 32. & Ngulet & $\begin{array}{l}\text { 32. Gantung sikil semu ndlosor mangjeng, badan jengkeng mewingking, suku } \\
\text { seleh, gantos gantung ingkang satunggal. Ngulet saged mlampah saged } \\
\text { manggen. }\end{array}$ \\
\hline 33. & Oyogan & $\begin{array}{l}\text { 33. Damel barisan selarik utawi sejajar, caranipun majeng mlampahipun } \\
\text { lenjitan utawi legehan, pethukan nrobos silang-silangan suku barisanipun } \\
\text { rapet terus ngoyog ngiwo / nengen } 4 \text { etangan. }\end{array}$ \\
\hline 34. & Kesodan & $\begin{array}{l}\text { 34. Pasangipun kalih kalihcaranipun kados oyogan. yen sampun adu bokong } \\
\text { wirogo kados untu walang. }\end{array}$ \\
\hline 35. & Kiprah & $\begin{array}{l}\text { 35. Sikap pokok polatan nengen asta tengen ukel ketarik sak nginggil bahu, } \\
\text { asto kiwo wiwit ngulur sampur kaseblakaken, gentosan kiwo-sami. Kiprah } \\
\text { puniko pinangka singgetan (elet2) antawis ragam kaliyan ragam sanesipun, } \\
\text { utawi kangge ngaso sawetawis. }\end{array}$ \\
\hline 36. & Tolehan Jonggo & 36. Nolah-noleh pacak jonggo. \\
\hline 37. & Jangga lenggutan & 37. Lenggut-lenggut. \\
\hline 38. & Ngebyek & 38. Asta kalih2 majeng lurus nabok-nabok. \\
\hline 39. & Nutul & 39. Asta ngiting nutul nutul ngiwa nengen. \\
\hline 40. & Tumpang tali & 40. Asta ngepel jempol ndengangak medal gerakkan minggah mendhak. \\
\hline 41. & Ngelis & 41. Ngithing main ugal \\
\hline 42. & Gebras & 42. Mencolot/jeblosan memper perangan-perangan. \\
\hline 43. & Njontrot & 43. Mencolot terus mlajar dateng gawang. \\
\hline 44. & $\begin{array}{l}\text { Kecakan (khusus } \\
\text { kangge tarian massal). }\end{array}$ & $\begin{array}{l}\text { 44. Ngambruk sempok kuda dipunangkat kanti nyuwanten E,e,e,o,o,e,e,e .......e } \\
\text { yaaa tumungkul kendel sawatawis. }\end{array}$ \\
\hline 45. & $\begin{array}{l}\text { Pejah//sirep (khusus } \\
\text { kangge tarian massal). }\end{array}$ & 45. Ambruk total mengkurep, utawi jengkeng. \\
\hline
\end{tabular}

The motion patterns that became the standard pattern in treating Jaranan above, did not fully describe the 
strength of a war horse. Motion patterns such as bapangan and kiprahan stressed the riders more in the form of dexterity. Perangan on Jaranan Temanggungan was also a depiction of the strength of war horses, so the movements mimicked the strength of war horses, such as how to hit the enemy, or themotion that show strength when attacking the opponent's horse. The development of tradition in Jaranan Temanggungan could be seen in the patterns of motion, costumes, and make-up that depicts the Mataram warriors.

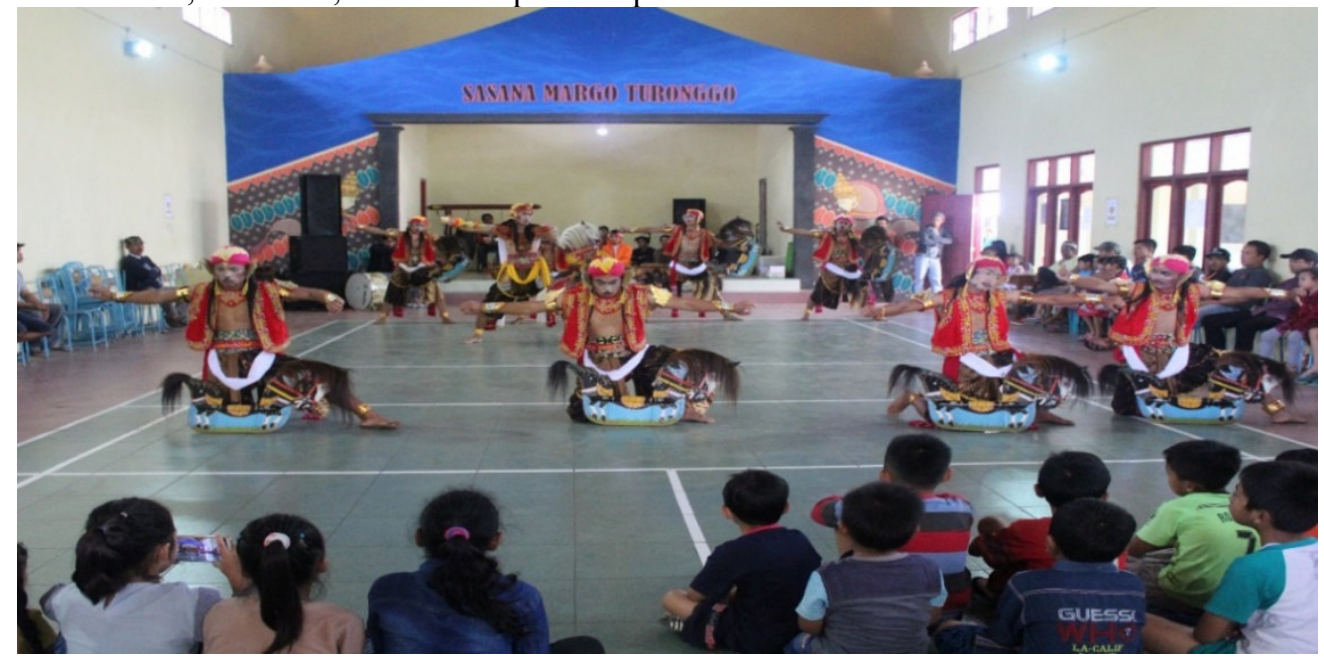

Pic. 1. Pose in Sembahan Motion (photo: Slamet 2019)

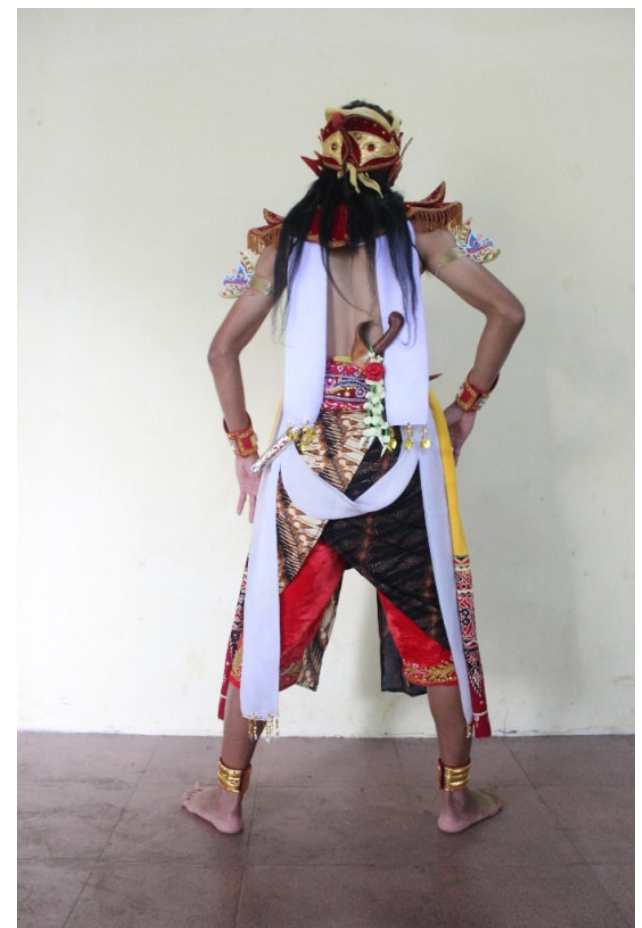

Pic. 2. Costume, Rear-look (photo: Slamet 2019) 


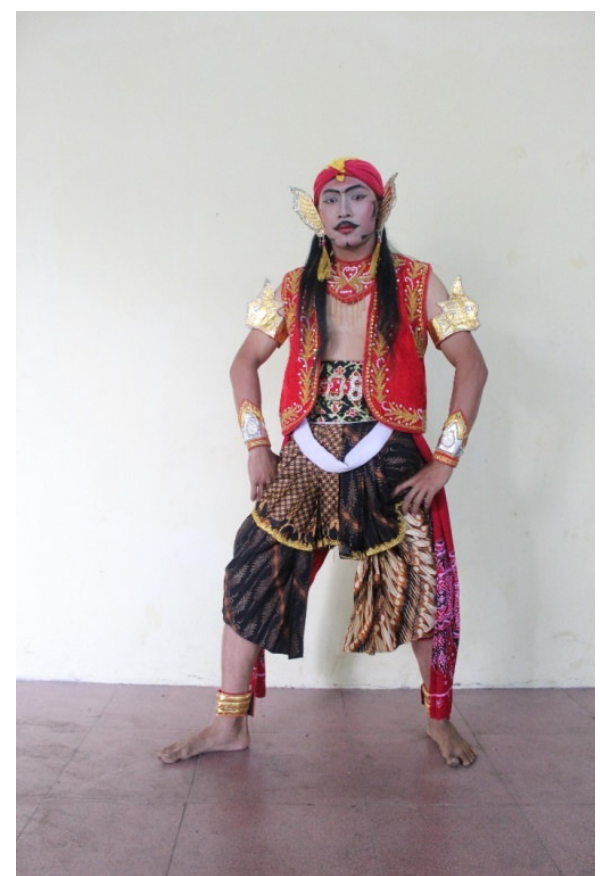

Pic. 3 . Costume, Front-look(photo: Slamet 2019)

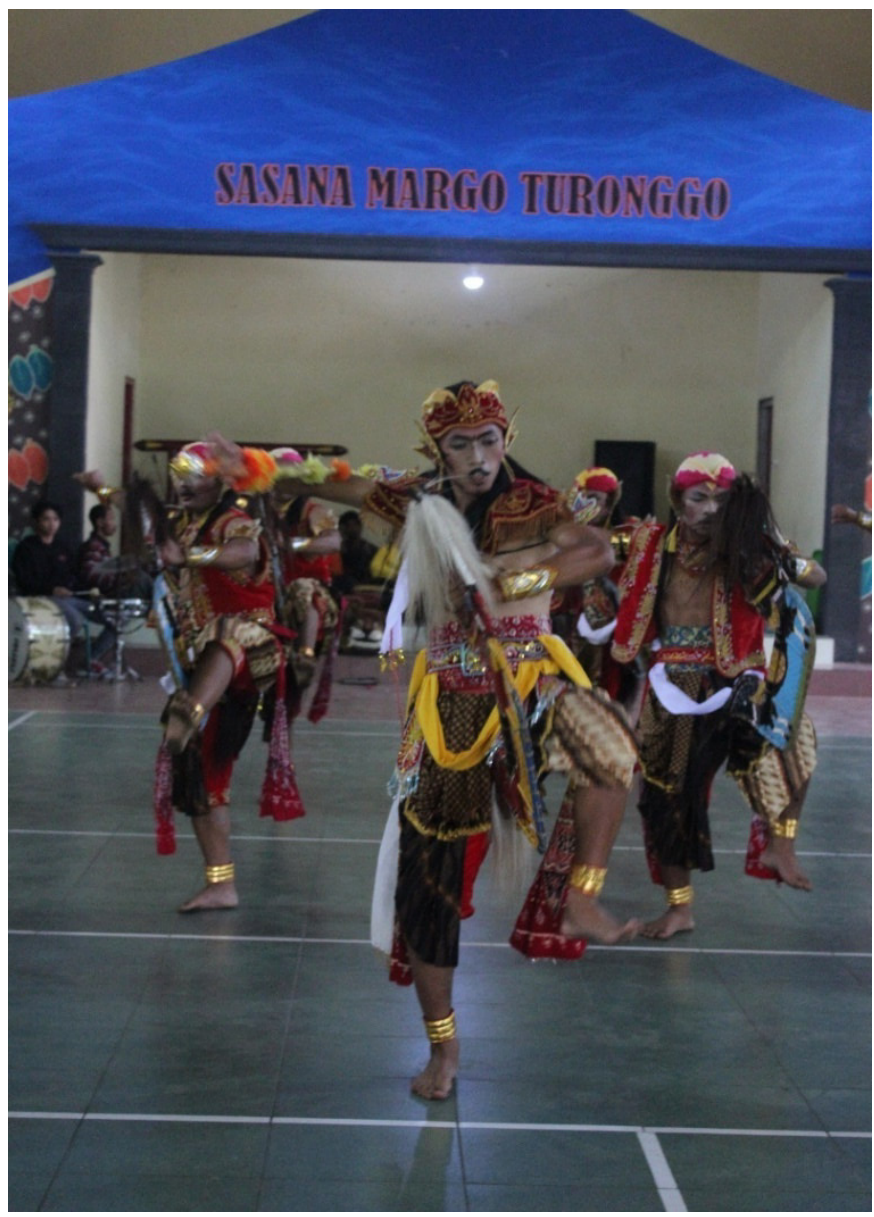

Pic. 4. Pose of Lampah Nyongklang (photo: Slamet 2019)

\section{Conclusion}

Jaranan Temanggungan was a form of Temanggung folk dance. This dance came from the belief of totemism, known as magical sympathetic. The presence of totemism could protect people who believed in its existence. 
Related to Jaranan in Temanggung and the Kapalan Margowati site, it could be understood that the formation of the Jaranggungan Temanggungan motion pattern came from worshiping horses as totem animals, so that people made dummy horses into jaran kepang.

The motion patterns created from the results of imitating horse's strength such as; ngombe, nyongklang, takur-takur, teposan, and all the motion patterns used in Jaranan dance were depictions of the strength of war horses. Jaranan Temanggungan motion pattern was a folk tradition. Based on the facts and studies, Jaranan Temanggung became an icon and was designated as an intangible Temanggung Cultural Heritage which was given its certificate on October 8, 2019 at Istora Senayan Jakarta. THe certificate was also based on the fact that Jaranan Temanggung was a folk tradition. It had experienced innovation that was still maintained by the current generation.

\section{References}

Alkaf, Mukhlas, "Spiritualitas Mistis di Balik Ekspresi Kesenian Rakyat Jaranan”,Acintya,Jurnal Penelitian Seni Budaya ISI Surakarta, Vol 1, No 12009.

Alifa Radhia, Hanifati, “Dinamika Seni Pertunjukan Jaran Kepang Di Kota Malang”, Jurnal Kajian Seni, Vol. 02, April 2016: 164-177

David E., Mauricio, “Jaranan of East Java: an Ancient Tradition”, Tesis Jurusan Theatre University of Hawaii, 2002.

Ahimsa-Putra, Heddy Shri(ed). Ketika Orang Jawa Nyeni. Yogyakarta: Galang Press, 2000.

Anoegrajekti, Novi. "Perempuan Seni Tradisi: Kontestasi dan Siasat Lokal”(Makalah disampaikan dalam Diskusi "Perempuan dalam Citra Visual dan Pertunjukan" di Komunitas Salihara, Kamis 21 April 2011).

Christensen, Paul. "ModernityandSpirit Possession In Java: Horse Dance and Its Contested Magic." DORISEA Working Paper 2 (2013): 1-13.

Holt, Claire. Melacak Jejak PerkembanganSeni di Indonesia. Bandung: MSPI,2000.

IDAKEB, “Kawruh Satjuwil Djaran Kepang”, Temanggung: IDAKEP, 1972.

Indra Udhi Prabowo, Fransiskus, "Pelestarian Kesenian Kuda Lumping oleh Paguyuban Sumber Sari di Desa Pandansari Kecamatan Sruweng Kabupaten Kebumen”, Jurnal Program Studi Pendidikan Bahasa dan Sastra Jawa Universitas Muhamadiyah Purworejo, Vol. 06 No. 01 April 2015.

Kaulam, Salamun, "Simbolisme dalam Kesenian Jaranan", dalam URNA Jurnal Seni Rupa, Vol. 1, No. 2, (Desember 2012)

Komajaya, terj. Serat Centhini, 1981

Koentjaraningrat,Pengantar Ilmu Antropologi, (Jakarta: Rineka Cipta, 2009).

Mareta Dewi Puspitasari, "Fungsi Kesenian Tradisional Jaranan Manggolo Yudho Dalam Upacara Adat Nyadran Belik Di Desa Sumbergedong Kabupaten Trenggalek," Skripsi Jurusan Seni dan Desain, Fakultas Sastra UM, 2012.

Nisa'u Fadhilla, "Peran Dan Fungsi Paguyuban Jaranan Wahyu Kridha Budhaya Kota Kediri, Jawa Timur”,Apron Jurnal Pemikiran Seni Pertunjukan UNESA, Vol 2, No 2, 2013.

Saraswati, Delvi, "Pengaruh Kesenian Bali Terhadap Bentuk Penyajian Kesenian Kuda Lumping di Desa Kentengsari Kecamatan Candiroto Kabupaten Temanggung, Skripsi Program Studi Pendidikan Seni Tari, Fakultas Bahasa dan Seni, Universitas Negeri Yogyakarta, 2016.

Suliyani, Tutik, Perkembangan Kesenian Jaranan "Samboyo Putro" DiDdesa Bandarlor Kecamatan Mojoroto Kotamadia Kediri Periode 1977-1996, Skripsi Jurusan Tari, Fakultas Seni Pertunjukan, STSI Surakarta, 1999.

Uli Rizky Nareswari,” Analisis Struktural Jaranan Senterewe Turangga Wijaya Di Dusun Sorogenen, Kecamatan Kalasan, Kabupaten Sleman”, Yogyakart," Skripsi Jurusan Seni Tari, Fakultas Seni Pertunjukan UNY, 2014 